\title{
EL MONÓLOGO DRAMÁTICO \\ EN LA POESÍA ESPAÑOLA CONTEMPORÁNEA: JOSÉ HIERRO Y PEDRO PROVENCIO
}

\author{
DRAMATIC MONOLOGUE \\ IN CONTEMPORARY SPANISH POETRY: \\ JOSÉ HIERRO AND PEDRO PROVENCIO
}

\author{
Carlos FRÜHBECK MORENO \\ Università degli Studi di Enna "Kore" \\ moreno.fruhbeck@unikore.it
}

Resumen: El objetivo de este artículo es aportar nuevas perspectivas sobre la lectura de la poesía con la ayuda de la teoría de la relevancia y la retórica. Con el monólogo dramático como punto de referencia, se prestará atención al estatuto del poema como texto persuasivo y a la naturaleza de la enunciación. Para terminar, se analizarán dos poemas de José Hierro y Pedro Provencio.

Palabras clave: José Hierro. Pedro Provencio. Poesía española contemporánea. Discurso poético. Monólogo dramático. Pragmática. Retórica.

Abstract: This paper aims to provide new perspectives on reading poetry with the support of Relevance Theory and Rhetoric. While studying dramatic monologue, we will focus on the poem as a persuasive text and on the characteristics of enunciation. Last, two poems by José Hierro and Pedro Provencio will be analyzed.

Key Words: José Hierro. Pedro Provencio. Contemporary Spanish Poetry. Poetic Discourse. Dramatic Monologue; Pragmatics. Rhetoric. 


\section{REFLEXIONES METODOLÓGICAS}

A la hora de estudiar las circunstancias de la lectura de un poema desde la teoría de la relevancia, tomamos como punto de partida que la falta de copresencia en ningún caso significa ausencia de contextos. Esto resulta así porque más que de necesidad de un contexto físico, se habla de la de un contexto psicológico, o información compartida entre los participantes; de la elección de la información pertinente dependerá el éxito de la comunicación. Esto se da en cualquier tipo de intercambio (Luján Atienza, 2005: 92). Por eso, también en el caso de la lectura de un poema el emisor deberá ser capaz de construir su enunciación de tal forma que "el receptor sea capaz de seleccionar el contexto en que [...] debe ser entendida" (Luján Atienza, 2005: 92).

A todo esto se debe añadir otro dato: en la lírica, resulta problemática la tensión que se crea entre el emisor, o sujeto empírico que produce el texto y el locutor, o ser que es presentado en el enunciado como su responsable, y al que remiten las marcas de primera persona (Ducrot, 1984: 257): la crítica ligada al estructuralismo y al formalismo tradicionalmente ha considerado que la enunciación lírica posee una naturaleza ficcional (Luján Atienza, 2005: 23). Por poner un ejemplo, para Sultana Wahnón (1998: 106-107), por su misma condición literaria, el yo del poema sería un hablante ficticio; sin embargo, el hecho de que identifiquemos automáticamente al sujeto empírico con el yo lírico ${ }^{1}$ hace que su ficcionalidad resulte difícilmente analizable.

Una exposición interesante de este problema nos la ofrece Dominique Combe: para el francés, existe una relación de naturaleza metonímica entre el sujeto empírico responsable del poema y el yo lírico que lo protagoniza. $\mathrm{Y}$ en este tropo convivirían el significado literal y el figurado en una tensión "nunca resuelta" (Combe, 1999: 152; Scarano, 2014: 24-26), como sucede en toda relación metafórica. De esta forma, el yo lírico sería una entidad en "perpetua constitución" (Combe, 1999: 153), siempre a medio camino entre lo singular y lo universal, entre lo

\footnotetext{
${ }^{1}$ Como se sabe, la aportación de Petrarca fue de capital importancia a la hora de establecer este protocolo de lectura en el que se dan la mano vida y literatura. En los poemas del Canzioniere crea la imagen del hombre moderno que tiene conciencia de sí mismo y establece lo que para Martín Estudillo (2007: 37) constituye la ficción de que hay una relación de identidad entre el yo lírico y el sujeto empírico.
} 
temporal y lo intemporal. En resumidas cuentas, en todo poema se daría una superposición de voces, una especie de "fisura entre ficción y realidad" que conferiría al género su capacidad de expresión (Ballart, 2005a: 190).

Para Luján Atienza (2005: 56), la problematicidad del yo poético, en realidad, nacería del hecho de que se propone al lector como si de un enigma se tratara: a través de los datos ofrecidos se debe reconstruir de forma creativa, se debe crear un contexto adecuado para su entendimiento. Y todo ello se debe hacer de acuerdo con las convenciones de la lírica. Esta actividad de reconstrucción de identidades se manifiesta de una forma muy particular en los poemas en los que la dicción se sostiene sobre el monólogo dramático. Su estudio, desde las coordenadas de la teoría de la relevancia y la retórica, puede aportar nuevos datos para comprender la naturaleza del sujeto en la lírica y, sobre todo, de qué manera se produce su interpretación.

Entendemos por poemas de monólogo dramático aquellos en los que el yo lírico se convierte de forma explícita — no hay intención de engañar al lector, hay un autor que firma el poema - en un personaje que, en primera persona, desvela progresivamente su personalidad y que no se identifica ni con el sujeto empírico que produce el texto ni con sus circunstancias (Cuvardic García, 2016: 171). El parlamento de este personaje se produce en un contexto espacio-temporal bien escenificado, y suele tener un destinatario ficticio que poco tiene que ver con el lector (Thanoon, 2009; Byron, 2003: 20-24). Este actúa entonces como una especie de mirón, como el espectador de una obra de teatro (Thanoon, 2009). Su función entonces será de naturaleza detectivesca: deberá inferir qué está objetivando exactamente el poeta en la voz del personaje (Cuvardic García, 2016: 175). Y es que habrá un fuerte contraste entre la literalidad de las palabras del monólogo y el mensaje que transmiten en realidad. De esta forma, se consigue que la interpretación del poema dependa tanto de la empatía que el personaje despierta, como del juicio moral que inspira (Langbaum, 1957), a pesar de todas las críticas que se pueden plantear a esta idea (Byron, 2003: 21-22). Se trataría de una versión del yo implícito, de crear en el personaje una suerte de correlato objetivo que funciona como mediador entre el emisor y el receptor (Prieto de Paula, 1996: 348362; Pérez Parejo, 2007). Para nosotros, el efecto del monólogo dramático resultaría similar al que se produce ante el espectáculo de un imitador de voces: el animador proyecta una imagen de alguien que no es él: su 
muñeco está siempre en primer plano; sin embargo, paradójicamente, con su misma presencia también se esfuerza por que los espectadores no se olviden que siempre es él mismo quien está hablando (Goffman, 2006: 555): él —y no su personaje — recibirá los aplausos.

Por su parte, el público espera que el imitador de voces se comporte en un cierto modo: debe desarrollar su espectáculo en una cierta situación; debe elegir un cierto tipo de registro según qué personaje elija; será adecuado que hable de unas cosas y no de otras, etc. Por tanto, en toda imitación se superpondrán —o más bien se mezclarán- dos voces: la del personaje imitado y la del imitador en concreto, que corresponde a una imagen más o menos idealizada que satisfaga las expectativas de sus espectadores (Goffman, 1997: 49). ¿Por qué, entonces, imitar la voz de los demás? Entre otros motivos, se hace para subrayar un cierto tipo de relación, sea de afinidad o no, entre el imitador y el imitado. El ventrílocuo también construye su propia identidad a través de sus personajes (Ballart, 2005a: 194-195). Las consideraciones de Sperber y Wilson a propósito del eco y la ironía son perfectamente aplicables:

Al representar el enunciado de una persona, o la opinión de un determinado tipo de personas, de una forma manifiestamente escéptica, divertida, sorprendida, triunfante, mostrando aprobación o reprobación, el hablante puede expresar su propia actitud hacia el pensamiento del que se hace eco, y la relevancia de su enunciado puede depender, en gran parte, de la expresión de esa actitud (Sperber y Wilson, 1994: 291).

En lo que se refiere a la imagen que el imitador debe dar como tal, Luján Atienza (2005: 148-150) cifra el éxito de un poema en la necesidad de que el poeta transmita una imagen de sí mismo que concuerde con su rol social. Para ser escuchado, un poeta debe hablar como poeta ${ }^{2}$. Y esto ocurre, como ya hemos adelantado, porque la lírica se caracteriza como un género en el que el plano del discurso domina sobre el plano de la historia: por ello, el lector tiene la sensación de encontrarse ante un acto de habla

\footnotetext{
${ }^{2}$ Nos referimos a un tipo de identidad situacional, dependiente de la situación comunicativa (Zimmerman, 2008: 94) que se combinará con las identidades discursivas y las identidades transportables; estas últimas hacen referencia a las características sociales de los individuos que participan en el intercambio.
} 
realizado en presente, e instintivamente identifica al locutor con el emisor (Mignolo, 1985: 132-133), a pesar de todas las máscaras que este utilice.

En este sentido, tiene particular interés el estudio de la enunciación desde la perspectiva de la retórica: vista la sensación de inmediatez que provoca la lectura de un poema, no habría dificultad en considerarlo como un texto persuasivo con un orador reconocible. Su éxito residirá entonces en que merezca la pena escuchar a dicho orador. Para Ballart (2005b: 75-76), los poetas en realidad construirían textos argumentativos fundamentados sobre el ethos ${ }^{3}$. Dicho de otro modo, el responsable del texto poético debe ser capaz de crear un espacio en común con el público. Por eso, es necesario recordar que toda presentación de sí estará modelada por las ideas dominantes, las reacciones y las expectativas del auditorio y que encontrará unos límites bien definidos a la hora de expresarse: los que impone el discurso en el que se insertan las propias palabras (Amossy, 2010: 87-90; Perelman y Olbretchs-Tyteca, 1966: 26-28) ${ }^{4}$. Obviamente, ofrecer una imagen positiva de sí no se limita a hablar bien de uno mismo: el ethos también se apoya en índices que van desde la elección del registro o del género, el ritmo o la facilidad de palabra (Maingueneau, 2002: 60). La poesía no constituirá una excepción.

Sin embargo, resulta insuficiente hablar simplemente de imagen social del poeta; nuestra exposición quedaría coja si nos dejáramos en el tintero un detalle fundamental: los poemas suelen estar firmados. Y es que, de acuerdo con Lejeune (1994: 59), "el nombre propio es donde persona y discurso se articulan antes mismo de articularse en la primera persona". La firma constituye una auténtica declaración de responsabilidades: a través de la nominación se instituye una identidad social constante, una defensa contra la impostura que impone claras obligaciones respecto a nuestras acciones, en este caso discursivas (Alberca, 2013). ¿Y qué significa esta responsabilidad? Ni más ni menos que el responsable del texto, el nombre propio, funciona como necesario contexto que guía la interpretación (Perelman y Olbretchs Tyteca, 1966: 335 y ss.); a pesar de que reproduzca una cierta imagen social de poeta, un mismo poema puede cambiar de

\footnotetext{
${ }^{3}$ Como señala al respecto Aristóteles en su Retórica, "en todo caso se ajusta más al hombre honesto aparecer como honrado que como riguroso en su discurso" (1418a, 39-42).

${ }^{4}$ Josu Landa (2002) se ha dado bien cuenta de la situación al cifrar en las preferencias subjetivas de una cierta comunidad poética las características que debe tener un texto poético para convertirse en ese acontecimiento que es el poema.
} 
significado dependiendo de quién lo firme. Por tanto, los límites de la interpretación de un poema están marcados no solo por la imagen de poeta que impone el contexto cultural y sus características discursivas, sino también por el ethos prediscursivo (McCroskey, 2016: 82-83) que el lector obtiene de quien firma. No nos podemos olvidar de que el éxito de un discurso depende de las características personales y sociales de sus fuentes (McCroskey, 2016: 87).

Por todo lo dicho, en este trabajo postulamos que la interpretación de todo poema toma como punto de partida una imagen ética. En esta imagen se manifiesta una tensión entre la dimensión social del artista como creador, con sus límites discursivos, y los conocimientos que tiene el lector sobre el autor concreto que se declara responsable del poema. Qué duda cabe que se trata de un concepto de naturaleza dinámica: la imagen ética variará de lector a lector, de acuerdo con su contexto cultural y con los conocimientos poseídos. Así se planteará la identidad del imitador de voces: una mezcla entre su individualidad y las exigencias que la sociedad impone a su espectáculo teatral. ¿Y qué relación existirá entre la imagen ética y el contenido del poema? Una de las funciones principales de este contenido será, a través de la obtención de inferencias, destacar unos elementos de la primera en detrimento de otros, para provocar así una serie de efectos cognitivos. En resumidas cuentas, el poema activa un tipo de imagen y la modifica. El resultado de la lectura del poema estará cerca entonces de lo que Maingueneau (2002: 65) denomina ethos efectivo, resultado de la interacción entre el ethos prediscursivo y la imagen que el poeta ha conseguido construir de sí mismo tras la lectura del poema.

Dicho esto, regresemos a la imagen social del poeta. Para este trabajo, nos centraremos en dos modelos. En primer lugar, nos fijaremos en uno fruto de la autonomía del campo literario con respecto al campo del poder. Como se sabe, con el advenimiento de la modernidad, el poeta no encuentra ya su espacio en la sociedad: queda convertido en una suerte de fantasma (Paz, 2003: 243). La poesía es un valor que no cotiza en bolsa; la valía del artista residirá no en la aceptación social, sino en la adquisición de un capital simbólico por realizar una obra crítica con los espectros de la comunidad de la que forma parte; su vivencia habitará en la marginalidad, tanto en la versión del dandi como en la del bohemio (Bourdieu, 1990: 16-17). Por eso, su escritura se situará fuera de las normas que el mercado impone a las producciones artísticas (Bourdieu, 1995: 85). Qué duda cabe 
que esta consideración social impone restricciones a la presentación de sí en la escritura: el poeta, para ser reconocido como tal, se deberá mostrar en público bajo la máscara del diferente (Vaillant, 2011: 29-33), de aquel que construye su vida sin respetar la reglas, como una obra de arte (Alberca, 2013). Se trata del mito del artista que vive en contacto con una visión privilegiada de la realidad que, paradójicamente, lo separa de los demás hombres (Kermode, 2002: p. 8 y ss.). De ahí que, en muchos casos, este sujeto caiga en el soliloquio, en la escritura que carece de destinatarios claros, en una actitud crítica ante los discursos establecidos que se manifiesta en la exploración de los límites del lenguaje.

Sin embargo, a pesar de todas las críticas que se han vertido contra este modelo, en cuanto que la diferencia se entiende como índice de aceptación de la injusticia (García Montero, 2003: 42-44), es innegable que su amplia consolidación en el imaginario social hace del marginado un interlocutor válido para el lector de poesía: la tradición del género y su situación en el mercado literario, basada también hoy en la adquisición de capital casi exclusivamente simbólico, no hacen más que consolidar esta situación. Ahora bien, este razonamiento tiene sus sombras: si el éxito de un buen discurso tiene que ver con la homofilia, o creación de un espacio común en el que público y orador se encuentran, comparten los mismos valores, actitudes y creencias (McCroskey, 2016: 99-100), ¿cómo justificar entonces que merece la pena escuchar al marginado? Desde nuestro punto de vista, porque en las palabras del marginado el público buscará una verdad que posee, pero de la que no tiene conciencia; buscará en el poeta su identidad última. Profundizaremos en este tema más adelante.

Otra imagen sería la del poeta comprometido, también ampliamente extendida en nuestra tradición artística: el poeta no se considera como un elegido condenado a la soledad, sino como un ciudadano más que a través de su arte busca que "nadie pueda ignorar el mundo y nadie pueda ante el mundo decirse inocente" (Sartre, 1967: 56). Negar paraísos visionarios significa proyectar al hombre a su realidad histórica e invitar al lector a cambiarla. Se trata de una imagen de poeta que goza de una amplia aceptación en la poesía española contemporánea: tendencias como la poesía social o la poesía de la experiencia, con su programa de crítica a la conversión del capitalismo en vida a través de una escritura capaz de producir nuevos modelos de intimidad (Rodríguez, 2016), son buena 
prueba de ello ${ }^{5}$. En la segunda parte de este trabajo veremos que estas dos imágenes, a pesar de las apariencias, no se oponen entre sí.

Si volvemos a las características del monólogo dramático nos encontramos con un dato curioso: el ventrílocuo a veces imita la propia voz; la expresión del personaje que habla en el poema está limitada por las características del género y por el estilo del responsable del texto. En otras palabras, en estos poemas, el ethos mostrado del poeta, modulado por las convenciones literarias (registro, ritmo, etc.) y su adecuación a las expectativas del lector de poesía, sirve como filtro para la expresión del personaje ${ }^{6}$. Y esto ocurre porque, desde nuestro punto de vista, entre personaje imitado e imagen ética, existe una relación metonímica que guía la interpretación. Veamos de qué manera funciona y a qué conclusiones podemos llegar.

Para la lingüística cognitiva, en la metonimia se establece una relación entre dos elementos que pertenecen a un mismo dominio cognitivo (Cuenca e Hilferty, 2007: 110). Se trata de un proceso en el que la dimensión referencial - se nombra una cosa en el lugar de otra - se conjuga con la comprensión: también sirve para concebir en un cierto modo un referente (Lakoff y Johnson, 2009: 74). Así ocurre porque el funcionamiento de este tropo consiste en que a través de un punto de referencia o entidad explícita nombramos una entidad implícita o zona activa (Cuenca e Hilferty, 2007: 110-111). En otras palabras, se nombra un elemento oculto a través de otro visible perteneciente a su mismo dominio. Y a través de la relación que existe entre ambos - y que se basa en nuestra interacción cotidiana con la realidad (Lakoff y Johnson, 2009: 75 y ss.) — se define la naturaleza del elemento escondido. Aplicado al tema de nuestro artículo, en los poemas de monólogo dramático el explícito personaje funciona como punto de referencia de la imagen ética, que sería la zona activa.

El paso sucesivo es explicar cómo nuestro sistema cognitivo

\footnotetext{
${ }^{5}$ Un tercer tipo de imagen sería la del misántropo ya totalmente alienado por la sociedad que lo rechaza. El escritor tendría conciencia de llevar una vida pobre y de su inutilidad para la comunidad: esto traería como consecuencia una perspectiva que se limita a complacerse en una intimidad enormemente frágil (Alberca, 2013).

${ }^{6}$ Críticos como Sinfield han observado bien esta situación. Por ello han hablado de la presencia de una suerte de "conciencia dividida" en estos poemas, que traería como consecuencia una suerte de "ironía dramática". Esta se traduciría en la presencia de dos actos de habla simultáneos en estos discursos: el literal del personaje y el inferido por parte del lector (Byron, 2003: 14-16). Nuestra interpretación está muy cerca de esta postura.
} 
procesa los tropos. Para ello, nos valdremos de la teoría de la relevancia. Esta teoría considera que la comunicación es algo más que la mera transmisión de mensajes codificados. De hecho, el significado codificado, dentro de las coordenadas que marca el contexto, será simple punto de partida para una serie de procesos de obtención de inferencias tanto del significado proposicional - las explicaturas - como del implícito - las implicaturas - . La obtención del significado final estará guiada por el principio de relevancia (Sperber y Wilson, 1994): a partir de un enunciado tenemos que inferir los contenidos que más enriquezcan nuestro conocimiento del mundo con el menor esfuerzo de procesamiento. En resumidas cuentas, la interpretación de un enunciado no está codificada, sino meramente sugerida (Sperber y Wilson, 2008: 90-91). Esto proporciona al lenguaje una grandísima capacidad de adaptación a los contextos más variados.

En el caso de la comprensión léxica, el significado de una palabra resulta modulado, ajustado, durante la comprensión, de acuerdo con las circunstancias. De esta forma, se crea un concepto ad hoc, adecuado solo para esa específica situación comunicativa (Carston, 2010: 303). Hay que señalar que este particular concepto puede contener el significado codificado o, al menos, superponerse sobre el mismo (Carston, 2002: 349). Se trata de una explicación válida para todos los casos: en la teoría de la relevancia no se establece ninguna diferencia de procesamiento entre lenguaje figurado y no figurado (Sperber y Wilson, 2008: 85).

Si tenemos que explicar por qué nos comunicamos a través de tropos, no viene mal recordar que, por un lado, el significado literal de una expresión no es siempre el más adecuado para la situación comunicativa: hay casos en los que un significado aproximado, reducido o ampliado con respecto a lo codificado convencionalmente (Sperber y Wilson, 2008: 96), resulta más relevante que un significado preciso. Por otro, en ocasiones nos vemos obligados a comunicar pensamientos complejos que no pueden representarse literalmente (Sperber y Wilson, 1994: 285). La metáfora constituiría un caso en el que una interpretación no literal, aproximada, puede ofrecer al interlocutor un rico haz de significados implícitos y no siempre parafraseables (Carston, 2010: 306-312).

A la hora de evaluar la transmisión de significado no viene mal recordar que en el continuum que va desde el significado determinado al indeterminado Sperber y Wilson sitúan el tropo poético en el extremo de 
la indeterminación: su significado sería difícilmente parafraseable (2015: 123). Este continuum entre lo determinado y lo indeterminado se combina con otro que va del decir (el significado NN de Grice) al mostrar (el significado natural). El tropo, con su significado indeterminado, se situaría a medio camino entre el mostrar y el decir: la expresión daría solamente una idea muy poco precisa de las conclusiones a las que se debe llegar. El objetivo sería crear una impresión. Por impresión, los dos filósofos entienden una modificación en el nivel de manifestación de una serie de proposiciones que atañen un cierto estado mental (Sperber y Wilson, 2015: 132 y ss.). En otras palabras, a través del tropo se busca que el lector tome partido por un punto de vista gracias a un argumento que no se puede expresar de forma proposicional.

Si deseamos perfilar mejor este haz de implicaciones no parafraseables - implicaturas débiles - que producen los tropos hay que recordar también que su procesamiento depende de los mismos circuitos cognitivos que gestionan la vivencia emocional (Lakoff 2016: 272 y ss.) y que las emociones están fuertemente ligadas a su dimensión evaluativa; por tanto, el lenguaje trópico será capaz de provocar un número más amplio de respuestas emocionales que el literal. De hecho, Blakemore (2011: 3544) señala que los tropos se caracterizan por la inefabilidad descriptiva en lo que se refiere al contenido evaluativo al que sirven como vehículo.

Un ulterior efecto de los tropos lo constituye su capacidad para activar imágenes mentales, más allá de inferencias conceptuales que realice el receptor (Carston, 2010: 318-319). Se trata de un efecto no desdeñable; de hecho, en poesía, en muchos casos, el éxito de un tropo no depende tanto de los significados de las formas lingüísticas sino de las imágenes que estas activen. Estas tienen un papel evidencial que se combina con los significados de las palabras a la hora de realizar las inferencias (Carston, 2010: 319).

Para terminar, hay que señalar que en casos en los que el tropo se extiende a lo largo de una superficie textual, su procesamiento no se limita a la mera producción de un concepto ad hoc. De hecho, este proceso solo se produce instantáneamente en enunciados breves que requieren poco esfuerzo de procesamiento (Carston, 2010: 307). En los casos en los que ocupa gran parte del texto, el esfuerzo es excesivo y los significados literales sobreviven, se sitúan dentro de un marco de interpretación o se metarrepresentan (Carston, 2010: 310), en el sentido de que se mantiene 
una suerte de significado flotante, listo para ser incluido posteriormente en una red de asociaciones. Esto lleva a una conclusión de interés: esta situación obliga al receptor a reconstruir su sentido del mundo de forma que se ajuste a la literalidad de las palabras (Carston, 2010: 310; Camp, 2009). Obviamente, las imágenes evocadas jugarán un papel más importante que en el caso en que se produce la simple creación de un concepto ad hoc (Carston, 2010: 320).

Las conclusiones a las que nos conducen estas premisas se sustancian, en primer lugar, en que en los poemas de monólogo dramático tiene lugar una identificación de carácter metonímico entre la imagen ética del poeta y el personaje que toma la palabra en el mismo. Como ya hemos dicho, la primera se convierte en una zona activa de la que el segundo subraya una serie de características; el lector las debe reconstruir en un ejercicio de interpretación autónoma. Lo hará a través de la realización de inferencias sobre los vínculos que unen al responsable del texto con el personaje que toma la palabra. Esta identificación tiene lugar en un contexto bien definido: el que imponen las convenciones de lectura del género lírico.

Visto el funcionamiento de la metonimia, tanto personaje como imagen ética conviven en el poema en tensión; nos encontramos ante el espectáculo de un ventrílocuo cuya identidad es construida a través de sus muñecos. Esto ocurre porque, al extenderse la metonimia por todo el poema, no se crea un concepto ad hoc de forma automática. El lector se ve obligado por ello a crear un universo que pueda dar sentido al texto que está leyendo en relación con la imagen ética — contexto ineludible del poema - a la que dichas palabras señalan. Por este motivo, el lector no podrá olvidar en ningún caso que estas palabras en realidad parten de dicha imagen ética del poeta. La función, entonces, del personaje que habla en el poema será modularla, destacar unos aspectos y no otros. Por eso, nuestro razonamiento tiene otra consecuencia estética muy interesante: el ventrílocuo, generalmente, hace escandalosamente mal su trabajo. El discurso de los personajes se suele plegar a las convenciones del discurso lírico y a las necesidades de la imagen.

Por otra parte, también se hace necesario recordar que este vínculo trópico no se puede parafrasear en su totalidad: estará formado por una red de implicaturas débiles en las que las respuestas emocionales ligadas a la dimensión evaluativa de la metonimia tendrán su protagonismo. Por eso, 
tampoco es baladí recordar que en este proceso de construcción poseerán gran importancia las imágenes mentales que evoque automáticamente el personaje protagonista a partir de su situación en el imaginario social. Por todo lo dicho, el objetivo final será conseguir que el lector tome partido por una nueva visión del mundo (Luján Atienza, 2005: 97-98).

De todas formas, ¿por qué el poeta elige el distanciamiento que supone todo monólogo dramático? Cierto es que obedece tanto a una voluntad de superación de los clichés del confesionalismo romántico a través de un pudoroso ocultamiento del yo (Prieto de Paula, 1996: 348 y ss.) como al planteamiento neobarroco de una identidad híbrida, quebradiza, inestable, reflejo quizá de la crisis que para las certezas establecidas resultó la modernidad (Martín-Estudillo, 2007: 37 y ss.). Sin embargo, este cuestionamiento de la lectura del yo poético como una entidad estable constituye también un instrumento persuasivo de primer orden: entre la imagen ética y el protagonista del poema se crea un vínculo en el que la dimensión cognitiva y afectiva se entrelazan, que no se puede parafrasear en su totalidad y que tiene como objetivo modificar la visión del mundo del lector a través de un ejercicio de lectura activa.

Una vez expuesto el planteamiento metodológico, se dedicará la segunda parte a su aplicación en el ámbito de la poesía española contemporánea. En nuestro contexto literario, a partir de su introducción gracias a Luis Cernuda, auténtico puente entre la poesía española y la inglesa (Carnero, 2004: 25), el monólogo dramático ha tenido un cierto éxito. Así lo demuestra su cultivo en primera instancia por parte de los poetas cercanos a la llamada poesía del conocimiento y, en segunda, por parte del grupo de los novísimos (Pérez Parejo, 2007). En estos poemas se entiende la escritura poética como, con Gil de Biedma, un ejercicio de construcción de un yo que "romp[e] el mito de la verdad psíquica como requisito de autenticidad poética" (Prieto de Paula, 2014). Entre otros elementos, el entendimiento del poema como ficción por parte de los poetas cercanos a la poesía de la experiencia consolidó ulteriormente su uso: buena prueba de ello nos la ofrecen libros como Vidas improbables de Felipe Benítez Reyes, organizado como un haz de voces apócrifas (Prieto de Paula, 2014).

Desde nuestro punto de vista, la aparición del monólogo dramático tiene que ver con una cierta voluntad de exploración tanto de la propia identidad como de la de la colectividad a través del distanciamiento que 
ofrece este recurso: como hemos dicho, el diálogo que se produce entre imagen ética y personaje protagonista revela siempre nuevas perspectivas sobre la primera. Con este horizonte de expectativas, nos ocuparemos de dos poetas aparentemente muy alejados entre sí: José Hierro y Pedro Provencio.

\section{ENSAYO SOBRE MÁSCARAS}

Una de las características más sobresalientes de Cuaderno de Nueva York, el último libro de José Hierro, es el distanciamiento enunciativo que se establece en muchos de los poemas a través del recurso al monólogo dramático. Para López Baralt, los resultados de este procedimiento se encuentran en la línea de lo ya señalado: a través del recurso al antifaz el poeta trata de llamar la atención sobre "el propio ser" (López-Baralt, 2002: 140), en la estela de uno de sus principales referentes estéticos, Lope de Vega (López-Baralt, 2002: 140-142; López-Baralt, 2002: 24 y ss.). Es más, los aspectos que revelará este ejercicio de desdoblamiento entrarán en el ámbito de lo no parafraseable: la identificación trópica es ante todo un ejercicio de indagación; el monólogo dramático servirá tanto para desdibujar el yo a través de la máscara como para permitirnos acceder en su emborronamiento "de manera más directa al alma del poeta que escribe porque lo que le interesa no es tanto que lo entiendan sino conocerse a sí mismo" (López Baralt, 2002: 148). Por su parte, Corona Marzol (1991: 297-300) considera, de forma más general, que este desdoblamiento en el cántabro se identifica con una manifestación de los conflictos propios de la modernidad: la ruptura interior de la propia identidad y la imposibilidad de aprehenderla de forma unitaria, de contemplarse y entenderse con un solo golpe de ojo. Para el autoconocimiento hay necesidad de ese prisma orteguiano que es la metáfora (Ortega y Gasset, 1964: 256-257).

Nuestra lectura del monólogo dramático como teatral superposición de dos voces permite, en la poesía de José Hierro, explicar en parte el concepto enunciación alucinada, propuesto por Saneleuterio Temporal: en la última poesía del cántabro es común que "se describ[a] algo supuestamente externo al yo, pero visualizado en su interior, de ahí que la subjetividad aparezca reflejada, siquiera de soslayo" (Saneleuterio Temporal, 2011: 200). Una de las manifestaciones de esta enunciación se sustancia en poemas de monólogo dramático en los que el yo lírico enuncia 
experiencias que se pueden tanto asignar al yo empírico como al personaje que funciona como correlato objetivo. Antonio Ortega a propósito de este fenómeno llega a una conclusión que se acerca bastante a la interpretación de que propondremos: "[a través de sus personajes, el poeta] constituye no sólo ya sus máscaras, sino unas voces que asumen y encarnan, sin artificio ya, la voz segura del poeta" (Ortega, 2001: 177). Obviamente, la presencia del responsable del poema no se limitará a la aparición de meros biografemas, sino que se manifestará en aspectos compositivos como el mismo ritmo, que leeremos como una estrategia persuasiva (Dennis, 2001: 18-20), o en una escritura difícilmente asociable a la dicción del personaje que se toma como punto de referencia. Nuestro comentario se centrará en "Ezra Pound", un poema perteneciente a la sección "Engaño es grande".

Qué duda cabe que la elección de Ezra Pound como protagonista no es banal. En Pound se combinan la adhesión al fascismo italiano con el rechazo de una sociedad consumista, la americana, que, después de considerarlo traidor, hacerlo prisionero y encerrarlo en una jaula, termina por segregarlo en un psiquiátrico. Esta situación convierte a Ezra Pound en un símbolo del enfrentamiento entre el poeta y la comunidad que lo rechaza, y ha tenido una cierta fortuna en nuestras letras. En particular, entre los miembros del grupo de los novísimos. Sin posibilidad de alargarnos más, nos basta con recordar poemas como el "Encuentro con Ezra Pound" de Antonio Colinas (2013), en el que la figura del poeta americano forma parte de un complejo tejido simbólico que acaba por desembocar en la corrupción y la muerte: "En esta callejuela sin macetas, / sin más salida que la muerte / vive Ezra Pound". Otro ejemplo nos lo proporciona Juan Luis Panero; el poeta, con cortante lucidez, lo convierte, en "Un viejo en Venecia" (2003: 85-86), en una especie de símbolo de la desesperación, independientemente de las circunstancias del Ezra Pound real ("Que el viejo Pound, desde su tumba, / me perdone por unir su nombre / a estas sórdidas palabras desesperadas" (Panero, 2003: 86)).

Si volvemos a Hierro, lo primero que hay que subrayar es que el poema está construido como una oscilación entre sus dos concepciones de la poesía: la alucinación y el reportaje. La primera y la tercera parte se pueden situar en la primera estética y funcionan como un marco que guía la interpretación del largo poema en prosa que conforma la segunda. Se trata de dos breves textos en los que un deliberado prosaísmo se conjuga con un elegante movimiento rítmico. Para Hierro, el reportaje constituiría 
un modo para, a través de la aparentemente fría exposición del hecho, sugerir "el contenido del corazón”, la huella que este ha dejado en el poeta (Corona Marzol, 1991: 304-305). Obviamente, la escritura no aspira a ningún grado cero; la selección de la información, su disposición y, sobre todo, la naturaleza del ritmo servirán de adecuadas pistas para establecer todas estas inferencias.

Veamos, entonces, la primera parte del poema. En este caso, no se escucha todavía la voz de Pound; nos encontramos con un yo que, a pesar de no aparecer de forma explícita, el lector siente como si estuviera "impregnando todo el texto, dirigiendo perspectivamente en un determinado sentido interpretativo" (Luján Atienza, 2005: 155). Este yo sería otro instrumento de persuasión: la información que ofrece sobre el hecho es la única accesible para el lector (Luján Atienza, 2005: 290):

Desconectado de su lugar y de su tiempo,

extravagante americano nacido en Gran Bretaña,

a contratiempo, a contraluz, a contralugar.

Todo, hasta su lengua materna,

le vino estrecho. Por eso recurría

al griego clásico, al latín,

al provenzal antiguo, al italiano del Dante, al chino.

En Spoleto salmodiaba

con susurro ancianisimo, en italiano,

—una sutil manera de venganza-

algunos de sus Cantos Pisanos,

escritos en inglés, como es sabido [...] (Hierro, 2017: 732).

La sencilla presentación de Ezra Pound se hace en un primer momento a través de una construcción absoluta y lo que presumiblemente podría ser una aposición explicativa. Estos elementos sintácticos solamente sirven para ofrecer una información adicional sobre la oración principal en el primer caso y sobre el sustantivo al que modifican, en el segundo. Lo que llama la atención es que ni el verbo ni el sustantivo están presentes: el lector debe inferir a qué se refieren ambos complementos. Para ello, cuenta con la ayuda de una nueva enumeración: "a contratiempo, a contraluz, a contralugar”. Entonces, ¿Pound vivió, sufrió, murió? $¿ \mathrm{O}$ es que al verbo que define la existencia del poeta solo nos podemos 
acercar por inferencias, por eludir una enunciación proposicional? Lo que queda claro es que la biografía de Pound se fundamenta en la negación, en el enfrentamiento con la sociedad en la vivía. En este sentido, se puede inferir que la adhesión al fascismo ("Esto ocurría años después / de su exaltación del fascismo / - Inglaterra mi natura, Italia mi ventura / USA mi sepultura", Hierro, 2017: 732) se sitúa dentro de este ejercicio de rebeldía más que en la posesión de una fe auténtica.

Obsérvese, en lo que se refiere al ritmo, cómo el poema está escrito en verso libre con relieve sintáctico (Provencio, 2017: 64 y ss.): a pesar de que dentro de los versos ocasionalmente nos encontramos con eneasílabos ("de su lugar y de su tiempo"; "extravagante americano") u otros metros clásicos, hay una voluntad de conseguir una identidad entre verso y secuencia sintáctica. En los casos en los que se produce el encabalgamiento, este no resulta brusco, aunque hay alguna excepción ("[...] Por eso recurría / al griego clásico, al latín"). Por todo lo dicho, hay que destacar el contraste entre la sensación de suave fluencia que transmite de forma general el poema y las bruscas detenciones que producen los incisos. Esto provoca en el lector una sensación de extravío: es como si el ritmo transmitiera tanto la firmeza como las contradicciones del personaje rebelde que presenta.

En la segunda parte, una vez contextualizada, ya escuchamos una voz que el ventrílocuo asigna a Ezra Pound. Aquí nos situamos dentro del terreno de la alucinación ${ }^{7}$ : este largo fragmento de prosa poética - tan cercano al monólogo interior - se presenta como una exploración de la intimidad torturada del poeta, como una forma de hacer explícito a través de un lenguaje con voluntad exploradora el magma interior de un Pound que pasa de la jaula al manicomio y que se puede interpretar como metáfora general del estatus del creador en la sociedad:

Mis cantos definitivos. Los de la plenitud y el miedo. Tengo miedo. Tengo — soy, estoy-jaula. Las palabras más eficaces las de mi lengua y las ajenas, vivas, muertas, oxidadas y aún hermosas,

\footnotetext{
${ }^{7}$ A la hora de interpretar la alucinación pensamos que más que hacer explícito a la razón el movimiento emocional de la intimidad del poeta, como sugiere Corona Marzol (1991: 319-327), es más productivo entenderla solamente como un modo alternativo de conocimiento a través de la poesía: se trata de una palabra "urgida a colmar un vacío existencial insoportable para el hombre" (Olivio Jiménez, 1964: 289).
} 
mágica como el chino, de llave inencontrable, como el bengalí. Miedo, jaula, escribo. Miro cada instante la puerta cerrada (Hierro, 2017: 733).

Las recurrencias léxicas obligan a interpretar el poema de tal forma que se establece una relación de correlación entre la fuerte imagen mental del poeta encerrado en la jaula, con la que se identifica, el terror y la creación definitiva. El ritmo discurre en este fragmento $-\mathrm{y}$ en el resto del poema- sostenido sobre un contraste entre periodos de una cierta longitud, llenos de enumeraciones y enunciados breves y cortantes. Esto provoca en el lector la sensación de encontrarse ante una fluencia imprevisible; como quería Benveniste (2010: 396), el poema se configura a través de un despliegue progresivo del discurso (Provencio, 2017: 119) como una entidad inestable, en continuo movimiento, como si de un río cuyo recorrido no conocemos se tratara. Obsérvese que este movimiento lingüístico casa muy bien con la descripción torturada de la creación poética que ya hemos planteado. Prosigamos:

[...] Tengo sangre, miedo, jaula. Tengo Dorothy, Shirley, Caroline, o como se llame esta mujer de verde y blanco almidonado. Me recorta la barba, me arregla el embozo de la cama, me anima a comercon voces desafinadas, como si me creyese tonto o sordo- esas comidas repugnantes que saben a clínico, a puritanos, a América, me inyecta y me hace tragar pildoras de muchos colores (Hierro, 2017: 733).

En este nuevo fragmento, la cinética se funda en la repetición de estructuras sintácticas: grupos de tres sustantivos (Dorothy, Shirley, Caroline; sangre, miedo, jaula), de tres sintagmas preposicionales o incluso verbales. Al igual que los esquemas métricos basados en la distribución acentual (Pilkington, 2000: 131 y ss.), esta recurrencia funciona tanto como un modo de destacar los elementos que forman parte de las secuencias como como una invitación a establecer asociaciones de naturaleza metafórica entre cada uno de estos miembros; de esta forma se crea una red de fuerte carga simbólica: la pueden formar los posibles nombres de la enfermera, la rutina del hospital y la civilización americana. Resulta imposible realizar una paráfrasis precisa de todas las implicaturas que se obtienen. Lo que sí 
que queda claro, simplificando mucho, es que se establece una relación de oposición entre el poeta y la sociedad. Y, como veremos a continuación, se da al acto de escribir el preciso estatuto de acto de liberación.

$\mathrm{Y}$ es que escribir no significa solo oponerse a la sociedad, sino también superar la temporalidad cronológica a través de la poesía. Se trata de uno de los pilares de la poética personal de José Hierro (López-Baralt, 2002: 31 y ss.): el objetivo último del poeta es conseguir una revelación, un instante afortunado que supere las asechanzas del mero fluir (Olivio Jiménez, 1964: 295 y ss.). En otras palabras, la voz de Ezra Pound empieza a convertirse en un vehículo para las obsesiones del cántabro. El imitador de voces está muy presente en sus personajes:

Sin papel, sin pluma mi mano. Así, ¿cómo sobrevivir, escribir, liberarme del tiempo? Traen el dolor: nada me importa. Del dolor irresistible nacen estos últimos cantos. Los más intensos que jamás pude soñar. Alguien - no sé quien - los entenderá. Tal vez T.S. Eliot los corrija y depure como yo corregí los suyos primeros. La jaula. Pero dentro. Fuera de ella escribo los últimos cantos que arranqué a la vida (Hierro, 2017: 733).

La liberación del tiempo se asociará a la liberación tanto de la jaula como de la sociedad, identificadas aquí entre sí de forma metafórica: escribir es trascender a ambas. Y para que esta trascendencia tenga lugar se hacen necesarios la soledad y el sufrimiento.

Como estamos viendo, aunque Pound también sea un poeta, su dicción como personaje manejado por José Hierro queda lejos tanto de las coordenadas del imaginismo como, posiblemente, del Pound real. Hierro lo elige por su valor simbólico para el lector de poesía y lo manipula para enriquecer su propia imagen ética. La causa de la adhesión al fascismo de Pound más que en la búsqueda de utopías residirá en el rechazo del mundo que le rodea, en la superación de su tiempo a través de la creación: “[y] o no soy un traidor a mi única patria que es la poesía. No quiero su [de la sociedad americana] comprensión, su compasión ni su desprecio" (Hierro, 2017: 734). Obviamente, en la tercera parte del poema, llega la conclusión previsible: el destino de esta obra desconocida, maravillosa, de la que solo conocemos el secreto de su creación es la desaparición. Así resulta la sentencia que dicta la sociedad. La redención del poeta solo puede quedar 
certificada a través de la destrucción del poema. Así trata la enfermera los Cantos que Pound le entrega en la última parte del poema:

\author{
[La enfermera] \\ Acto seguido, como hace \\ todos los días, \\ arroja al incinerador \\ vasos y platos de cartón, cubiertos de plástico. \\ Finalmente, como todos los días, \\ los papeles que escribe el loco \\ de la habitación 109 (Hierro, 2017: 735).
}

Todo lo que hemos expuesto nos lleva a concluir que Hierro desea destacar una serie de rasgos de su imagen ética: poeta será quien se rebela contra la sociedad establecida. Pero no se trata de una rebelión solo contra sus instituciones, sino también contra sus lenguajes y, sobre todo, contra su tiempo. Por otra parte, este poema constituirá también una reflexión sobre el acto de crear: la poesía es de naturaleza efímera e hija del rechazo. Qué duda cabe que el hecho de que el poeta haga hablar a Pound con una voz muy similar a la que encontramos en el resto de los poemas del libro sirve para que el lector establezca más fácilmente la asociación metonímica entre imagen ética y personaje ${ }^{8}$ : no nos engañemos, Hierro no tiene ningún interés en que Pound sea un disfraz perfecto, más bien le interesa a qué tipo de conclusiones puede llegar el lector por el hecho de que se identifique con él. Por todo lo dicho, la ficcionalidad o no del yo poético será un asunto secundario: el poema será un texto persuasivo y los juegos con la enunciación servirán para revelarnos una serie de aspectos del orador. El resultado dependerá de la mezcla entre el conocimiento que tenga el lector de la biografía de Hierro (su paso por la cárcel, su cercanía al grupo de los poetas sociales, sus poéticas del reportaje y la alucinación, por ejemplo) y la imagen social de poeta que activa este texto.

En lo que se refiere a Pedro Provencio, nos centraremos en su último libro de poemas, Onda Expansiva, publicado por Amargord en 2012, y uno

\footnotetext{
${ }^{8}$ Por todo lo que estamos diciendo, no es sorprendente que en "Rey Lear en los Claustros", nos encontremos en los labios del personaje de Shakespeare versos herederos de Unamuno o Salinas (López-Baralt, 2002: 158-161) o explícitas referencias a autores contemporáneos como ValleInclán.
} 
de las pocas producciones poéticas que nacieron del trauma social que supusieron los atentados terroristas del 11 de marzo de 2004 ${ }^{9}$. Si seguimos la línea del realismo especulativo, estos atentados se presentan como una muestra de la imposibilidad de controlar la existencia de fenómenos como el mal; son constatación de que independientemente de nuestra reflexión, de nuestra persecución del conocimiento, existen eventos en la realidad que escapan a la lógica humana (Meillassoux, 2015). Por su parte, Deleuze (2011: 181-183) entiende el acontecimiento como lo que debe ser comprendido, ser representado en el accidente, en el suceso; es lo que ya existía pero que se encarna, porque las doctrinas nacen de "heridas y aforismos vitales". Es por eso que este libro parte de las consideraciones de que "el ser humano que muere por voluntad ajena adquiere una realidad inesperada e insoslayable" (Provencio, 2014: 8) y que, cuando esta muerte encuentra justificaciones abstractas, este "queda siempre con un gesto interrumpido de ir a decir algo" (Provencio, 2012: 8).

En lo que se refiere a su estructura, Onda expansiva se construye como un coro en el que las voces de las víctimas se mezclan entre sí de forma armoniosa a través de la superposición de varios motivos: la reflexión sobre la naturaleza del mal en una larga reescritura del libro de Job, la identidad de la mujer en una sociedad que la margina, los conflictos que nacen cuando la cultura se da de bruces con lo Real, o la naturaleza del mismo acto de creación ante un acontecimiento que supera la comprensión humana.

En este libro es como si la muerte hubiera otorgado a las víctimas el ejercicio de la poesía con un objetivo claro: denunciar las ideologías que disfrazan la destrucción de los cuerpos — que es siempre el objetivo final de la guerra y el terrorismo - con la máscara justificativa de la misión trascendente o el beneficio económico (Scarry, 1987: 62-63). Sin embargo, esta conversión de los asesinados en autores no se traduce en la simulación de sus voces particulares, como sucede en otros libros cuyo hilo conductor también es la muerte, como Antología de Spoon River de Edgar Lee Masters. Todo se queda en la atribución de textos cuyo responsable final se identifica rápidamente como el poeta. El ventrílocuo mueve sus labios

\footnotetext{
${ }^{9}$ Hay que recordar aquí dos libros colectivos que salieron a la luz el mismo 2004: 11-M. Poemas contra el olvido, publicado por Bartleby y Madrid, once de marzo, publicado por Pre-Textos, al cuidado de Eduardo Jordá y José Mateos.
} 
visiblemente.

La justificación de esta actitud es que la función del artista se reduce a la de un intérprete que más que crear descubre el significado de la realidad que le rodea a través de una suerte de ejecución musical. De esta forma, uno de los muertos apostrofa en el primer poema del libro:

Arpista, pon tus manos

sobre los huesos de mi cara.

Busca la música [...] (Provencio, 2012: 11).

Por lo mismo, a lo largo de toda la obra es frecuente la imagen del escriba: el poeta se presenta como quien se limita a transcribir el significado de la masacre a través de la renuncia a sí mismo: "El escriba evita ser identificado bajo su escritura: busca el tiempo de letra que desoriente a cada lector" (Provencio, 2012: 157). Su labor está destinada al fracaso: la armonía final resulta misteriosa; no hay respuestas concluyentes después de haber escuchado la voz de todos. Para el último de los muertos, "[e]1 escriba ha encontrado la pieza / que faltaba en el arpa pero no / sabe qué hacer con ella. [...]" (Provencio, 2012: 226).

A pesar de todo, a pesar de negar que el poeta sea un creador, nos encontramos con una imagen social emparentada con la del marginado en contacto con una visión que lo separa de los demás hombres. Para nosotros, este intérprete tiene mucho que ver con el poeta considerado como antena de la raza, como ser dotado de una capacidad de percepción superior que le permite simplemente captar lo que ya estaba ahí pero que no veían los demás hombres (Pound, 2000: 87-88), tal y como defendían los imaginistas. En este caso, la poesía estaba en los labios de los muertos. De interés es cómo se va construyendo progresivamente esta imagen a lo largo de la lectura del libro, en este coro de voces que se define a sí mismo de forma indirecta como "caleidoscopio roto" (Provencio, 2012: 202).

Sin embargo, el poeta-antena se identificará también con el poetaciudadano: en su percepción privilegiada se sustanciará una crítica a los lenguajes establecidos, a los discursos dominantes; por ello, podemos situar este libro en la órbita de la llamada poesía de la conciencia crítica: hay una voluntad de descubrir las contradicciones presentes en estos discursos a través de una actitud vitalista (García Teresa, 2013: 37 y ss.), porque el canto de estos muertos equivale, en realidad, a un canto a la vida. La herida 
abierta que son las víctimas del atentado terrorista nos ofrece a través de sus voces una interpretación comprometida de la realidad. Veamos un ejemplo para ilustrar nuestro razonamiento:

Juan Francisco Pastor Férez

(España, 1953-2004)

pero, ¿cómo vas a resucitarlos?

eso sería emplear tu poder al margen de toda previsión salvífica

algo así como independizar tu ser de tu poder: imposible:

puedes manejar la masa del universo como si liaras un cigarro,

puedes subdividir hasta el infinito las partículas subatómicas,

pero no puedes restituirme a una sola de mis mujeres, a uno solo de mis hijos

porque tu poder ha de manifestarse como entropía a secas,

como querencia de muerte y no de vida, por eso tu mano derecha es Satán,

por eso, óyeme bien, que te adore Satán,

yo no te adoraré jamás, óyelo, Dios de Satán y de ti mismo,

seas el Dios que seas de tanto poder, maldito seas,

poco te afecta a ti mi maldición, lo sé, pero ya ves:

tú que lo puedes todo, menos apiadarte de inocentes,

no puedes conseguir que yo te adore,

tampoco lo pretendes, ni lo necesitas,

pero yo lo proclamo para oírmelo bien: yo reniego

de ti, yo te maldigo,

yo:

Job.

[no se conforman con nada

la Bolsa sube]

Jerusalén, Jerusalén, ¿a qué Dios te has convertido? (Provencio, 2012: 153-154).

Se trata de un de juego de muñecas rusas: la interpretación del poetaescriba descubre en los labios de Juan Francisco Pastor Férez un poema en 
el que el enunciador es Job. El efecto de la identificación metonímica entre víctima del terrorismo y personaje bíblico provoca la sensación de que la injusticia que es su muerte tiene dimensiones universales: es como si esta muerte concreta fuera encarnación de un acontecimiento que siempre ha afligido a la humanidad: la presencia del mal en el mundo. El haz de implicaturas que extrae el lector posee una gran riqueza: para empezar, la muerte de Pastor Férez se sitúa en unas coordenadas muy concretas de la tradición judeocristiana. Pastor Férez se ha convertido en encarnación del acontecimiento: su muerte sirve para producir sentido.

Sin embargo, no podemos detenernos aquí: el problema posee muchas otras facetas: el punto de fuga de esta enunciación en realidad no es Pastor Férez, sino la imagen ética de Pedro Provencio, una imagen en la que, como hemos visto, se entrecruzan una percepción privilegiada de la realidad con el compromiso cívico. En realidad, esta conversión de la víctima en encarnación de un enigma universal tiene su origen en el poeta: también él está explícitamente presente en las palabras que pronuncia Pastor Férez a través de Job; y estas palabras se pueden asociar a una tradición literaria. Así lo confirma, por ejemplo, el análisis de la dimensión rítmica del primer bloque textual; hay en este una relación meramente oblicua con la escritura bíblica. En realidad, tiene más qué ver con el versículo nacido en el siglo XIX junto al verso libre (Provencio, 2017: 138). Este se caracteriza por explorar el desarrollo de la enunciación a través de su expansión en un espacio imprevisible (Provencio, 2017: 137); en este caso la progresión de los versículos apoyada en el léxico de la física produce una sensación en la que se mezclan la frialdad y el ahogo. Por otra parte, a medida que avanzamos, la longitud de los versos se va reduciendo progresivamente hasta concentrarse en el pronombre y en el nombre propio. Llama la atención el encabalgamiento que hay entre los verbos 16 y 17 ("yo reniego / de ti. Yo te maldigo"). Sirve para destacar tanto el verbo como el complemento de régimen. Es como si, a través del encabalgamiento, el yo lírico alzara la voz al blasfemar.

En otras palabras, el punto de fuga siempre resulta la imagen ética del poeta; independientemente de los juegos enunciativos, el lector siempre será consciente de estar leyendo un libro firmado por Pedro Provencio. La modulación que produce el texto está relacionada con sus intenciones persuasivas: descubrir al lector que el mal, como veremos a continuación, tiene mucho que ver con las contradicciones de los credos que justifican 
la matanza en nombre de la divinidad (García Teresa, 24 de diciembre de 2013).

El primer bloque de este poema se constituye en una suerte de diálogo con la tradición que intenta explicar el misterio del mal. Como se sabe, en la obra bíblica, Job, tras ser despojado de sus bienes, de sus seres queridos y de la salud por causa de una apuesta entre Dios y Satán, termina por quejarse a Yahvé de su estado, por poner en tela de juicio la dimensión ética de la deidad: para una moral basada en la ley de retribución su situación no se puede justificar (Ricoeur, 2004: 453454). Sin embargo, en la teofanía final, Dios prefiere no dar ningún tipo de respuesta a sus interrogantes; no necesita justificar sus acciones ante nadie: es simplemente autor de una creación grandiosa, de un orden que escapa a la comprensión del hombre. Esa es la razón, para Ricoeur (1994: 205), por la que esta obra nos conmueve tanto. Job terminará por adorar a Dios $a$ pesar de, por adorarlo por nada a cambio (Ricoeur, 1994: 219), porque su grandeza siempre estará más allá de los límites del entendimiento humano. Ahí residirá la victoria del Creador sobre el Adversario.

Sin embargo, el Dios que aparece en la larga reescritura del libro de Job que atraviesa Onda expansiva tiene una dimensión mucho menos abismal. Más bien se presenta como una construcción discursiva que oculta unos intereses claros: las servidumbres económicas y sociales que justifican la masacre. Así queda claro en la breve historia narrada por Ionut Popa (Provencio, 2012: 165-169) en otro poema: dos jóvenes violinistas inmigrantes piden a Dios que resucite a su padre, víctima del atentado. Dios lo hará solo si consiguen que uno de los grandes bancos del mundo done el dinero que atesora a los pobres de la tierra. Los bancos se niegan a donar su dinero; siempre ponen como excusa que deben proteger los intereses del mismo Dios. Así ocurre hasta llegar a las más humildes cajas de ahorros. Ante la queja de los dos hermanos por las condiciones que la deidad impone, nos encontramos con una respuesta en la línea de la presente en el libro de Job. Sin embargo, vistas las circunstancias, la interpretación es bastante diferente:

Dios les respondió airado que si osaban pedirle explicaciones de Sus actos, los arrojaría de Su presencia, ¿o acaso no les importaba a ellos recuperar a su padre, al precio que fuera? ¿Quién les mandaba hacerse preguntas de calado teológico? [...] ¿No habian 
aprendido en el colegio elemental en Rumanía ni en el Instituto de Secundaria en España que los designios de Dios son impenetrables? [...] (Provencio, 2012: 167).

Al final de la historia, Dios les pide que se conformen con solicitar una beca municipal de estudios; él se encargará de inspirar a los funcionarios del ayuntamiento. No resucita al padre de los jóvenes, pero les asegura que "gozará alguna vez de eterna bienaventuranza" (Provencio, 2012: 169). Los jóvenes, caricatura de Job, aceptan los designios divinos. No se nos escapa que esta parodia tiene su finalidad: demostrar que Dios no es tan inescrutable como parece y que en sociedad se convierte en máscara que oculta intereses bastardos. Como señala Eagleton (2010: 140-41), la perversidad está más relacionada con procesos sociales que con actos individuales. Y esto se puede aplicar a la barbarie que narra el libro.

Por eso, en este poema, vista la presentación de Dios en la sociedad como interesada construcción discursiva, visto que los asesinatos han sido cometidos en su nombre, Job decide rebelarse precisamente por la naturaleza del poder gigantesco del Creador: fuera de los discursos humanos su poder se vuelve "entropía a secas", es decir, una suerte de caos que solo puede crear dolor: de ahí su mayor cercanía a Satán. La solución se concreta en la blasfemia lanzada a la inmensidad. Obsérvese el contraste que se produce entre este primer nivel textual y los otros dos en los que se divide el poema, como ocurre en el resto del libro: a la desesperación de Job se opone una mera constatación económica. En resumidas cuentas, nos encontramos con un Dios inhumano que, paradójicamente, es servidor de los peores intereses humanos. Como se señala en otro poema, "[n]o te fíes del amor de Dios" (Provencio, 2012: 209). El contraste que produce el tercer bloque textual del poema no hace sino confirmar nuestro punto de vista.

\section{CONCLUSIONES}

Nuestro objetivo ha sido ofrecer una nueva aportación metodológica para entender mejor la naturaleza de la enunciación poética. A partir de la consideración del poema como texto persuasivo, hemos razonado cómo el punto de partida de la lectura es siempre una imagen ética del autor en la que se mezclan una imagen social con sus circunstancias concretas. 
Sin embargo, aquí nos hemos encontrado con varios problemas: el estatuto más o menos ficcional del yo poético y el hecho de que el lector automáticamente identifique al yo poético con el yo empírico del poeta. Para su estudio, hemos tomado como punto de referencia los poemas de monólogo dramático. En estos, explícitamente el yo poético se convierte en un personaje que no tiene que ver con el yo empírico. Con la ayuda de la teoría de la relevancia, hemos razonado cómo entre imagen ética y yo poético se produce una identificación metonímica. Su efecto será destacar una serie de elementos de la imagen ética en detrimento de otros, con los consiguientes efectos cognitivos. Las implicaturas obtenidas muchas veces serán débiles $\mathrm{y}$, por lo tanto, no parafraseables. Por ello, no será desdeñable su dimensión emocional.

Por otra parte, también hemos visto que en este tipo de poemas se produce una convivencia entre imagen ética y personaje: por ser esta metonimia un tropo que se extiende sobre todo el texto, el lector se ve obligado a construir universos en los que las palabras tengan sentido, a construir un contexto para ellas. A modificar la imagen ética que toma como punto de partida, en suma. A causa de esta superposición, no sorprende que las palabras del personaje protagonista estén en deuda directamente con la citada imagen ética. Al final, esta será siempre el punto de fuga.

El análisis de los poemas de José Hierro y Pedro Provencio ha confirmado nuestra perspectiva: en ellos, el personaje elegido (Ezra Pound y Juan Francisco Pastor Férez, una víctima del 11-M) sirve para enriquecer la imagen ética del poeta a través de los efectos cognitivos propios de la identificación metonímica: en José Hierro, la elección de Ezra Pound servirá para subrayar la condición del poeta como opositor a los discursos establecidos. En el caso de Pedro Provencio, el delicado juego de muñecas rusas que se crea en los poemas de Onda Expansiva resulta útil para dar un significado universal a la muerte injusta del atentado terrorista y para desarrollar una imagen ética en la que una aguda percepción del mundo se combina con el compromiso cívico.

\section{REFERENCIAS BIBLIOGRÁFICAS}

ALBERCA, M. (2013). El pacto ambiguo. De la novela autobiográfica a la autoficción [Formato Kindle]. Madrid: Biblioteca Nueva. 
AMOSSY, R. (2010). La présentation de soi: Ethos et identité verbale. Paris: Presses Universitaires de France.

ARISTÓTELES (1999). Retórica. Madrid: Gredos.

BALLART, P. (2005a). El contorno del poema. Barcelona: El Acantilado. (2005b). "Una elocuencia en cuestión o el ethos contemporáneo del poeta”. Signa. Revista de la Asociación Española de Semiótica 14, 73-104 (también en http://revistas.uned.es/index.php/signa/article/ view/6112 [05/04/2019]).

BENVENISTE, E. (2010). Problemi di linguistica generale I. Milán: Giuliani / Il Saggiatore.

BLAKEMORE, D. (2011). "On the Descriptive Ineffability of Expressive Meaning". Journal of Pragmatics 43, 3537-3550.

BOURDIEU, P. (1995). Las reglas del arte. Génesis y estructura del campo literario. Barcelona: Anagrama.

BYRON, G. (2003). Dramatic monologue. Londres: Routledge.

CAMP, E. (2009). "Two varieties of Literary Imagination: Metaphor, Fiction and Thought Experiments". Midwest Studies in Philosophy 33, 107-130.

CARNERO, G. (2004). Poética y poesía. Madrid: Fundación Juan March (también en https://recursos.march.es/culturales/documentos/ conferencias/gc48.pdf [08/02/2019]).

CARSTON, R. (2002). Thoughts and Utterances. The Pragmatics of Explicit Communication. Malden / Oxford / Victoria / Berlin: Blackwell Publishing.

(2010). "Metaphor: Ad hoc Concepts, Literal Meaning and Mental Images". Proceedings of the Aristoelian Society 110, 607-23.

COLINAS, A. (2013). Obra poética completa [Formato Kindle]. Madrid: Siruela.

COMBE, D. (1999). "La referencia desdoblada. El sujeto lírico entre la ficción y la autobiografía". En Teorías sobre la lírica, F. Cabo Aseguinolaza (ed.), 127-153. Madrid: Arco Libros.

CORONA MARZOL, G. (1991). Realidad vital y realidad poética en José Hierro. Zaragoza: Prensas Universitarias de Zaragoza.

CUENCA, M. J. y HILFERTY, J. (2007). Introducción a la lingüistica cognitiva. Barcelona: Ariel.

CUVARDIC GARCÍA, D. (2016). "El monólogo dramático en el discurso poético". Káñina. Revista de artes y letras XL.1, 167-182. 
DELEUZE, G. (2011). Lógica del sentido. Barcelona: Paidós.

DENNIS, C. (2001). Poetry as persuasion. Athens: University of Georgia Press.

DUCROT. O. (1984). El decir y lo dicho. Buenos Aires: Hachette.

EAGLETON, T. (2010). Sobre el mal. Barcelona: Península.

GARCÍA MONTERO, L. (2003). La casa del jacobino. Madrid: Hiperión.

GARCÍA-TERESA, A. (2013). Poesía de la conciencia crítica (19872011). Madrid: tierradenadie Ediciones.

(24 de diciembre de 2013). "Un texto para cada una de las víctimas del 11-M". La república cultural, https://larepublicacultural.es/ article7960 [08/02/2019].

GOFFMAN, E. (1997). La presentación de la persona en la vida cotidiana. Buenos Aires: Amorrortu. (2006). Frame Analysis. Los marcos de la experiencia. Madrid: Siglo XXI Editores.

HIERRO, J. (2017). Poesías completas (1947-2002). Madrid: Visor.

KERMODE, F. (2002). Romantic Image. Londres / Nueva York: Routledge. LANDA, J. (2002). Poética. México D.F.: Fondo de Cultura Económica.

LANGBAUM, R. (1957). The Poetry of Experience. The Dramatic Monologue in Modern Literary Tradition. Londres: Chatto and Windus.

LAKOFF, G. y JOHNSON, M. (2009). Metáforas de la vida cotidiana. Madrid: Cátedra.

LAKOFF, G. (2016), "Language and emotion”. Emotion Review 8.3, 269273.

LEJEUNE, P. (1994). El pacto autobiográfico y otros estudios. Madrid: Megazul-Endymión.

LÓPEZ-BARALT, L. (2002). Entre libélulas y ríos de estrellas: José Hierro y el lenguaje de lo imposible. Madrid: Cátedra.

LUJÁn ATIENZA, A. L. (2005). Pragmática del discurso lírico. Madrid: Arco / Libros.

MAINGUENEAU, D. (2002). "Problèmes d'ethos". Practiques: linguistique, littérature, didactique 113-114, 55-67.

MARTÍN-ESTUDILLO, L. (2007). La mirada elíptica: el trasfondo barroco en la poesía española contemporánea. Madrid: Visor Libros.

McCROSKEY, J. C. (2016). An Introduction to Rhetorical Communication. 
A Western Rhetorical Perspective. Oxon / Nueva York: Routledge. MEILlASSOUX, Q. (2015). Después de la finitud. Ensayo sobre la necesidad de la contingencia. Buenos Aires: Caja Negra Editora. MIGNOLO, W. (1982). "La figura del poeta en la lírica de vanguardia". Revista Iberoamericana 118-119, 131-148.

OLIVIO JIMÉNEZ, J. (1964). Cinco poetas del tiempo. Madrid: Ínsula. ORTEGA, A. (2001). "La naturaleza del sujeto poético en José Hierro". En Espacio Hierro. Medio siglo de creación poética de José Hierro, J. A. González Fuentes y L. Oliván (eds.), 167-178. Santander: Fundación Marcelino Botín / Universidad de Cantabria.

ORTEGA y GASSET, J. (1964). "Ensayo de estética a manera de prólogo". En Obras completas. Volumen IV, 247-264. Madrid: Revista de Occidente.

PANERO, J. L. (2003). Antología. Sevilla: Renacimiento.

PAZ, O. (2003). El arco y la lira. El poema. La revelación poética. Poesía e historia. México D.F.: Fondo de Cultura Económica.

PERELMAN, C. \& OLBRETCHS TYTEKA, L. (1966). Trattato dell'argomentazione. La nuova rettorica. Turín: Giulio Einaudi Editori.

PÉREZ PAREJO, R. (2007). “El monólogo dramático en la poesía española del siglo XX: ficción y superación del sujeto lírico confesional del Romanticismo". Espéculo. Revista de estudios literarios, 36, https://webs.ucm.es/info/especulo/numero36/monodram.html [08/02/2019].

PILKINGTON, A. (2000). Poetic effects. A relevance theory perspective. Ámsterdam / Filadelfia: John Benjamin's Publishing.

PRIETO DE PAULA, Á. L. (1996). Musa del 68. Claves de una generación poética. Madrid: Hiperión.

(2014). "Poesía en la era de la perplejidad". En Las moradas del verbo. Poetas españoles de la democracia. Antología [Formato Kindle], A. L. Prieto de Paula (ed.). Madrid: Calambur.

POUND, E. (2000). El ABC de la lectura. Madrid: Edición y Talleres de Escritura Creativa Fuentetaja.

PROVENCIO, P. (2012). Onda expansiva. Madrid: Amargord. (2017). Un curso sobre verso libre. Madrid: libros de la resistencia. RICOEUR, P. (1994). Fe y filosofía. Buenos Aires: Docencia / Almagesto. (2004). Finitud y culpabilidad. Madrid: Trotta. 
RODRÍGUEZ, J. C. (2016). "La poesía y la sílaba del no (notas para una aproximación a 'La otra sentimentalidad' y la poética de la experiencia". En Palabra heredada en el tiempo. Tendencias y estéticas de la poesía española contemporánea (1980-2015), R. Sánchez (coord.), 9-26. Madrid: Akal.

SANELEUTERIO TEMPORAL, E. (2011). "En la carne desnuda la escarcha”. Modalización lírica y construcción simbólica en la poesía de José Hierro [Tesis doctoral]. Valencia: Universidad de Valencia.

SARTRE, J. P. (1967). ¿Qué es la literatura? Buenos Aires: Losada.

SCARANO, L. (2014). Vida en verso: autoficciones poéticas. Santa Fe: Ediciones UNL.

SCARRY, E. (1987). The Body in Pain. The Making and Unmaking of the World. Oxford: Oxford University Press.

SPERBER, D. y WILSON D. (1994). La relevancia. Comunicación y procesos cognitivos. Madrid: Visor Libros.

(2008). "A Deflationary Account of Metaphor". En The Cambridge Handbook of Metaphor and Thought, R. Gibbs (ed.), 84-105. Cambridge: Cambridge United Press.

(2015). "Beyond Speaker's Meaning". Croatian Journal of Philosophy 15.44, 117-149.

THANOON, A. J. (2009). "Los requisitos formales del género del monólogo dramático". Espéculo. Revista de estudios literarios 41, https:// pendientedemigracion.ucm.es/info/especulo/numero41/ monodram.html [08/02/2019].

VAILLANT, A. (2011). "Entre persona y personaje. El dilema del autor moderno". Lingüística y literatura 60, 19-33.

WAHNÓN, S. (1998). "Ficción y dicción en el poema". En Teoría del poema: la enunciación lírica, F. Cabo Aseguinolaza (ed.), 77-110. Ámsterdam / Atlanta: Rodopi.

ZIMMERMAN, D. H. (2008). "Identity, Context and Interaction". En Identities in Talk, C. Antaki \& S. Widdicombe (eds.), 87-105. Londres: Sage.

Recibido el 27 de febrero de 2019.

Aceptado el 2 de abril de 2019. 